\title{
Partnership Governance as A Base for Strengthening Regional Tourism
}

\author{
Muchamad Zaenuri* and Atik Septi Winarsih
}

Lecturer of Government Studies Universitas Muhammadiyah Yogyakarta, Indonesia

$\begin{array}{ll}\text { ARTICLE INFO } & \text { ABSTRACT } \\ \text { Keywords: } & \text { Bartnership Governance } \\ \text { Tourism } & \text { Batu City as a city that has a popular tourist destination also faced } \\ \text { with this problem. Some tourist objects and attractions (ODTW) and } \\ \text { cultural events have been carried out through cooperation between the } \\ \text { three pillars of tourism, but until now still encounter various obstacles } \\ \text { that are generally not based on partnership. Paper is downloading said } \\ \text { the cooperation between the government and the private sector and } \\ \text { the community at events travel "Stone Flower Festival" in Batu based } \\ \text { on partnership. In this event developed the concept of a new } \\ \text { partnership to be able to give a theoretical explanation of the } \\ \text { phenomena associated with the implementation of regional tourism } \\ \text { affairs. With the new concept of partnership, clarity is gained about } \\ \text { the role of stakeholders, the policies developed by the government } \\ \text { and the impacts on stakeholders. The developed partnership is equal } \\ \text { and autonomous, sharing benefits and risks, pooling of resources, } \\ \text { high intensity, and valid for a long period. By using qualitative } \\ \text { research methods and using interview techniques, focus group } \\ \text { discussions and observations, this study of tourism partnerships } \\ \text { results in the finding that the roles of each stakeholder are in } \\ \text { accordance with their capacities, policies taken by the Batu City } \\ \text { Government have led to partnerships through sharing management } \\ \text { and resources, and the impact of the partnership brings an increase in } \\ \text { local own-source revenue and community income. Recommendations } \\ \text { that can be submitted so that the Batu Flower Festival event can be } \\ \text { continued and involve a wider community and more massive } \\ \text { promotions. }\end{array}$

\section{Introduction}

This research is motivated by the existence of empirical problems in the administration of tourism affairs by the local government, especially in Batu City which requires reinforcement for the organization of tourism events. Research from Zaenuri (2015) shows that the administration of tourism affairs in the region cannot be effective if it is not supported by other stakeholders such as the private sector and the community. In organizing tourism affairs, Batu City also cooperates with various stakeholders among other private companies and community groups providing tourism products and services.

Even though tourism affairs for the region are not mandatory but are optional, in Kota Batu the contribution made to economic development is very significant. Tourism can provide a multiplier effect for the growth of other productive economic activities. Tourism can create new jobs and can overcome poverty (Damanik, 2005) and can provide welfare for people in the region (Damanik 2010). Private and public involvement in tourism activities is a necessity, in

* Corresponding Author E-Mail Address: muchamadzaenuri@umy.ac.id 
general the government has limitations in providing public good and services, including in tourism activities. These limitations are stated by (Dwiyanto, 2012: 90) as follows:

"As public needs for public services increase and when the capacity of government bureaucracy is increasingly limited, the involvement of the private sector and the public in public services is a necessity. The dominance of government bureaucracy in various aspects of community life is doubtful. The strengthening of the flow of democratization raises the need to empower communities and stakeholders outside the government bureaucracy in the delivery of public services. Especially when service aspirations become higher, community involvement in the delivery of public services is no longer a necessity, but has become a necessity".

The conditions related to government limitations in tourism affairs allow the role of the private sector to increase. Interaction between the government and the private sector allows for a shortterm, win-win or long-term cooperation contract, likewise the interaction with the community will enable the existence of community empowerment programs around tourism objects that are increasingly diverse and applicable. Interaction and cooperation between the government and the private sector in good practice is referred to as good governance.

An effort to realize good governance in the field of tourism are certainly not easy because the three pillars of governance do not have the same and parallel capabilities and positions. As stated by (Dwiyanto, 2012) that cooperation between the government and the private sector / community has so far been limited to cooperation between the work owner and nongovernmental institutions as vendors or contractors. Such cooperation is nothing more than a sale and purchase transaction of goods and services between the government as the principal and the private sector or the community as an agent. Cooperation tends to be more short term with limited relationship intensity as stipulated in the clause in the contract.

The problems raised by Dwiyanto certainly lead to new thoughts to develop concepts that can solve these problems, the new concept in question is governance based on partnership (partnership) which in the public administration science by some experts is called the concept of partnership governance (Hall, 1999; Zadek \& Redovich, 2006, Munro, 2008; Dwiyanto, 2012) .

The application of the concept of governance in the administration of tourism affairs for local governments in Indonesia is already familiar. Batu City Government has practiced this concept in various objects and tourist attractions (ODTW) and also in organizing certain events, one of which is the "Batu Flower Festival" event. The management of this activity applies the concept of governance which is realized in the form of cooperation with the private sector which is formally institutionalized. Likewise there are tourism activities carried out in collaboration with community groups, cultural and artistic events are prominent examples of tourism activities that directly involve community groups.

Interactions that have occurred between the government, the private sector and the community are still contractual in nature and there is no sharing of risks. Most of the activities of the Tourism Department are not yet a partnership. Batu City Government as a principal will look for partners to work on programs or activities and partners as agents who will carry out the work or program. Batu City Government as the owner of the work and partners or nongovernmental institutions as vendors or contractors. Some development in Batu mostly done by using a pattern like that, so that more cooperation is transactional purchase.

The issue of partnership in tourism management also occurs in the Greater Malang area where Batu City is part of it. Study from Rachayuningsih (2010) shows that the partnership between stakeholders consisting of the local government of the tourism industry and the tourism community still has not occurred high synergy. Partnership that exists as a late were still dominated by the government. From this background it is necessary to formulate the problem include: How can the role of government, private sector and communities in the implementation 
of "Stone Flower Festival "? What are the policies taken by the Batu City Government in partnership? How do impact partnership for stakeholders?

\section{Research Method}

To find out the strengthening of partnership-based tourism, qualitative research methods are needed using descriptive techniques. The choice of research location is in accordance with the topic in the form of organizing a partnership-based tourism event using interview, documentation and observation techniques at the research location. Data analysis was carried out by identifying the role of the solder that was then sought by the degree of closeness to show the partnership pattern that had existed

\section{Result and Disscussion}

\subsection{General description of Batu Flower Festival event activities}

The Batu Flower Festival event or also called the Flower Car Parade in Batu City has been held routinely every year which usually coincides with the Rl Anniversary and the Anniversary of Batu City. This activity was held with the aim of moving the economy of the City of Batu through a monumental event, providing a means of creativity to artists and flower craftsmen in the City of Batu, providing interesting and quality entertainment to the public and tourists visiting the City of Batu as well as a means of tourism promotion in the City of Batu.

This activity was coordinated by the Batu City Tourism and Culture Office in collaboration with the Batu City PHRI and the Decorative Flower Farmers Association (Gapoktan) in Batu City, which was participated by all Regional Apparatus Organizations (OPD), Villages and Villages as well as government and private agencies in Batu City. The form of activities is a decorative car parade with the following conditions:

a. Participants of the Batu Flower Festival are decorative cars with floral materials such as decorative flowers, garden flowers, cut flowers or dried flowers or those made of paper, cloth, stereofomes or other similar material.

b. The shape of the decorative car is adjusted to each theme, preferably leading to technology and aesthetics.

c. If there is a companion who walks as a companion for an ornamental car, the costume used must be made and flowers or other materials made such as flowers.

d. Decorative pedestrians and escorts of a maximum of 30 (thirty) people.

e. Participants representing their respective institutions do not represent the Village.

f. Speeches or attractions are only allowed in the area designated by the committee with the duration of each speech or attraction for 5 to 10 minutes.

g. Participants must maintain the safety of their respective ornamental cars both at start, on the go and at the finish.

To motivate each participant to display their creations to the fullest, the committee provides an assessment and award by determining the 10 (ten) participants with the best performance, with rating criteria, namely the suitability of the theme to the appearance, creativity, especially related to technology, beauty, order, neatness and overall appearance.

\subsection{Partnership policy in the "Batu Flower Festival" event}

The policies that underlie the implementation of the Batu Flower Festival event are the Mayor's Decree and the Decree of the Head of the Tourism and Culture Office of Batu City. The composition of the committee involved various elements ranging and elements of the City Government of Batu which involved several Regional Apparatus Organizations (OPD), elements of community organizations such as KNPI, private elements such as PHRI and 
elements of society namely culture, cottage art and a combination of ornamental farmer groups. The composition of the committee for ornamental flower festival activities is regulated in the Decree of the Head of Batu City Tourism Office Number: 814/768/ 422.207 /2017.

If we look at the policy of the Batu City Government in managing the Batu Flower Festival events as mentioned above, the involvement of various elements ranging and elements of the City Government, in this case the Batu City Tourism and Culture Office, the private sector consisting of the PHRI and Jatim Park management, as well as the involvement of community elements consists of ornamental flower plant farmers or a group of ornamental flower farmer groups (Gapoktan) in Batu City. Although each year the composition of the committee changes, the involvement of the three elements, namely the government, the private sector and the community, always appears in the involvement of the management of the Stone Flower Festival.

\subsection{Partnership initiative in the Batu Flower Festival event}

The initial initiative for the partnership between the City Government of Batu, the private sector and the community in managing the Batu Flower Festival activities is the government party, in this case the Batu City Tourism and Culture Office. This is because this event is included in the work programs and activities that have been listed in the Batu City Regional Budget every year and are included in the East Java Province Tourism calendar.

The initial initiative originated from the Government was also strengthened by the Decree of the Mayor of Batu and the Decree of the Head of Tourism and Culture of the City of Batu which consisted and the composition of the organizing committee of the Batu Flower Festival which consisted of government elements, private elements and community elements and the duties and division of their respective roles the party.

\subsection{Partnership needs in the Batu Flower Festival event}

In seeing the needs, reasons or factors of externalities for these actors or actors to collaborate or collaborate with other parties in the Batu Flower Festival activities are as follows:

a. For private parties this activity is used as a promotional tool for tourist visits to hotels and other tourist attractions. Commodities that can be sold so far for tourists to visit Batu City are natural beauty and cool air, if tourists are also treated to a variety of interesting events that can be displayed in Batu City, it is hoped that they will be a special support for tourists to visit Batu City, other than because natural beauty factor.

b. For the community, especially the ornamental flower farmer groups, this event is a means to sell their merchandise or commodities so that this event can be a separate market segment for farmers. If this activity has been scheduled every year with the time that has also been set, then for ornamental flower farmers can prepare and plan in such a way that when needed not to run out of stock of flowers that must take and flower farmers and old Batu City.

c. For Batu City Government, the perceived impact is to increase Local Revenue and some sectors, such as parking fees, advertisement tax and more macro, it is hoped that this event will increase community income and economic growth.

\subsection{Actors and parties involved in the Batu Flower Festival event activities}

The actors or actors involved in the Batu Flower Festival event are the Batu City Government, in this case the Batu City Tourism and Culture Office, the private sector, namely the PHRI of Batu City and the community of ornamental flower farmer associations 10 incorporated in the Farmers Group Association (Gapoktan) flowers ornamental in the City of Stone with each different role division. 
The City Government of Batu plays the role of organizer and Gapoktan acts as a provider of decorative flowers while PHRI plays a role in the promotion of tourism whose main activity is to introduce events to hotel guests visiting Batu City, the role is seen as in the following table:

Table 1.

Actors and Roles in the Batu Flower Festival event

\begin{tabular}{clll}
\hline No & Party & \multicolumn{1}{c}{ Culprit } & \multicolumn{1}{c}{ Role } \\
\hline 1 & Government & Batu City Tourism and Culture Office & Implementation and funding coordinator \\
2 & Public & $\begin{array}{l}\text { Association of Farmers Group (Gapoktan) } \\
\text { ornamental flowers Batu }\end{array}$ & Flower providers and festival performers \\
3 & Private & PHRI Kota Batu, Jatim Park & Promote activities and provide lodging \\
\hline
\end{tabular}

\subsection{Impact of partnership}

The partnership between the Batu City Government, the private sector and the community in managing the Batu Flower Festival event has had both positive and negative impacts. The following outlines the impacts on Batu City Government, impacts on the private sector and impacts on Kota Batu communities.

\subsubsection{Impact of partnership on Batu City Government}

When the Batu City government has established the vision of Batu City as a tourism centre, the consequence is that it must be vigorous in promoting the potential of Batu City to the outside world. This task cannot be carried out by the Batu City government itself due to the limitations of its financial sub-resources and other resources, without involving other parties, namely the private sector and the community.

One of the activities aimed at increasing tourism promotion is the Batu Flower Festival event, which is coordinated by the Batu City Government through the Tourism and Culture Office. In its implementation the Tourism and Culture Office of Batu City did not carry out these activities independently, but cooperated with the private sector, in this case the PHRI and the community, namely the Combined Decorative Flower Farmer Group in Batu City.

Determination of the time of the implementation of the Batu Flower Festival event on the recommendation and the PHRI on the grounds if the implementation is set at the weekend it will attract tourists to visit Batu City considering the Batu Flower Festival has been included in the main event on the East Java Province Tourism calendar. In addition to this event included in the East Java Province tourism calendar the PHRI and hotel and restaurant owners also promoted this activity through the distribution of leaflets in collaboration with the tour and travel agents, as conveyed by Ms. Setyawati from the Department of Tourism and Culture of Batu City:

"To promote the Batu Flower Festival event, we collaborate with PHRI and travel tours as well as Jatim Park by distributing leaflets to these travels as well as to hotels and even the East Java Park moves themselves through their own access. The hotel and travel bureau network determines the dissemination of this tourism event "(Interview at the Office of Tourism, 18 May 2018)

The impact of the partnership in managing the Batu Flower Festival obtained for the Batu City Government is the task of promoting Batu City to become lighter, assisted by the private sector. Likewise, in the context of increasing the income of the community it was helped by the holding of the event.

\subsubsection{The impact of partnerships on the private sector}

Event Batu Flower Festival has a significant impact on tourist visits to Batu, especially for guests who stay at hotels. As stated by one of the hotel owners in Batu, the following: 
"Stone Flower Festival enters an impact on a significant increase for guests staying at our hotel. Even though there are quite a lot of visitors to this event, the average community and Batu region don't have to stay overnight at the hotel, but it is also interesting for visitors from outside the city because they have been promoted well in advance. In the future, it will be improved for participants from outside the area, so that the echo will be wider, so that it will have an impact on increasing the number of guests staying at hotels" (Interview, May 19, 2018)

Besides recognition from hotel owners, an increase in the number of tourist visits is also felt by innkeepers or hotels that are not starred, as stated by the following lodging owners:

"With this event I am certainly very happy because the lodging that I own has sold and there is a significant increase in tourists. From the notes I obtained from the guest book, it can be seen that the surge in visitors reached 50\%. This increase has never happened in ordinary times." (Interview, May 20, 2018).

The impact of the partnership in the form of organizing events turned out to be able to increase the number of tourists, not only in star hotels but also in lodging. From interviews with several other tour operators also showed the same conditions, the travel agency also showed an increase of $40 \%$.

\subsubsection{Impact of partnership on the community}

As a sample of the implementation of the Stone Flower Festival which was attended by approximately 80 (eighty) participants with the following details:

a. Element of Village and Village as many as 24 ornamental cars

b. Combined elements of hotel and tourist entrepreneurs as many as 7 ornamental cars

c. Combined elements of farmer groups of 3 ornamental cars

d. School elements are 25 ornamental cars

e. The elements of the Regional Apparatus Organization (OPD) are 15 cars

Premises $\mathrm{n}$ assumption of costs for the procurement of 1 (one) unit of the float approximately US \$ 5 million to \$ 7 million and the revenue can be generated and the event Stone Flower Festival for growers of ornamental flowers will be very encouraging considering all the flowers used in this parade come from farmers in Batu City area, therefore this event is really awaited for ornamental flower farmers, as stated by one of the Gapoktan members of ornamental flowers, namely chrysanthemum flowers, as follows:

"My income is gross every day between Rp. 200,000.00 (two thousand million rupiah) to Rp. 500,000.00 (five hundred thousand rupiah). But if there is a flower carnival like this it can be up to Rp. 1.000.000,00 (one million rupiah)." (Interview, 21 May 2018). A similar sentiment was also conveyed by one of the participants of the decorative car parade To the village of Mojorejo, as follows:

"There are three decorated cars that a right we show in the Stone Flower Festival. Each car will be decorated with about 1.5 million flowers, and various types. Three decorative cars Will be displayed, among others, themed classic cars, temples and pagodas in accordance with the eternal potential of Mojorejo and Tourism Park. One ornamental car minimum spend as much as Rp. 4 million. The flowers will be used to decorate the taken car and Batu City products themselves". (Interview, 21 May 2018). In addition to having a positive impact on ornamental flower farmers, especially on increasing income, this event also provides many benefits for traveling food and beverage traders because so many visitors who watch this decorative car parade make itinerant food and beverage vendors selling their wares around the location and route of the event This also experienced an increase in income, as conveyed by Mr. Shaleh, the meatball seller from Pendem Village below: 
"On a normal day I annihilate the right of beef approximately $1,5 \mathrm{~kg}$ and income between Rp. 1,250,000. up to Rp. 1,500,000. but if there is a flower carnival like this it can cost up to $3 \mathrm{~kg}$ of beef and my gross income can 13 reach $R p$. 2,500,000 up to Rp. 3,600,000. Because of this, the government often holds activities like this". (Interview, 21 May 2018).

Every Batu Flower Festival event can be ascertained that all the streets that are passed by this decorative car parade route will surely experience traffic jams as conveyed by the Batu City Police Officers as follows:

"This afternoon Batu Tourism City will be jammed because the city center lane will be closed completely starting at 10:00 WIB associated with the implementation of the annual flower festival so the implementation of this activity uses the city center lane. The road that is crossed is Sultan Agung Street, Agus Salim, Gajah Mada and Panglima Sudirman. This is the middle lane, although later the road will creep up, I estimate it will not be a total traffic jam, with the condition that the community meets the police's recommendations." (Interview, 21 May 2018).

Facing road congestion on motorbike or motorcycle taxi services is much in demand by visitors because it is more flexible to road congestion so that many motorcycle taxi drivers in Batu City also feel an increase in income due to the Batu Flower Festival event, as conveyed by Mr. Ardi, a resident of Tiekung Village who works everyday motorcycle taxi drivers:

"On an average day my gross income is between Rp 100,000. up to Rp. 150.000. before cutting the gasoline is less than 1.5 liters or around Rp. 12 .000. But if you're no crowds like these roads so jammed I get income Rp. 250,000 to Rp. 30,000." (Interview, May 22, 2018).

For the public, such as Mr. Ardi as a motorcycle taxi driver or Mr Sabar as a meatball trader, the actual event was not the Batu Flower Festival event but the crowd's element. With the crowd many visitors come and buy their wares. So what is expected for small communities like them is events or activities that bring a crowd that is often held in Batu City. E vent Stone Flower Festival much impact positive for society, especially in the income increasing, they are mainly growers of ornamental flowers, food and beverage vendors circumference and motorcycle transportation services.

From these findings it can be analyzed that the roles of each stakeholder are proportional. The government plays a role in planning and providing facilities related to the festival, the private sector promotes widely and the community through farmer groups provides flowers to be decorated. In accordance with the limitations of the partnership proposed by several experts, the Stone Flower Festival has been carried out in partnership and all parties have shared benefits, resources and management. This shows that the partnership has reached a comprehensive and autonomous partnership, each party can carry out its role independently for the wider interests.

Even though the partnership has been tightly and comprehensively established, its sustainability is still unclear. By looking at the success of the implementation of the Stone Flower Festival which is now of course continued for years to come. This is because all parties feel that they are benefited and increase the local revenue. The implementation of tourism affairs by the Batu City Government was helped by the Batu Flower Festival.

\section{Conclusion \& Recommendation}

Based on the findings and analysis it can be concluded that the stakeholders involved in the partnership provide a very decisive role, the roles are synergistic with each other and can achieve the goals set. The policy taken by the City Government of Batu is very appropriate by giving freedom to the private sector and the community to be involved in tourism events. Batu Flower Festival tourism event activities have a positive impact on the government, the private 
sector and the community, especially the people increasing their income. Recommendations that can be given to the Batu City government are that this tourism agenda must be continued and improved in quality in a sustainable manner, for the private sector to be more aggressive in conducting promotions, and for the community to be more creative in displaying attractions.

\section{References}

Damanik, Janianton, 2005, "Kebijakan Publik Dan Praksis Democratic Governance di Sektor Pariwisata”, Jurnal Sosial Politik, UGM, Yogyakarta.

Damanik, Janianton, 2010, "Merancang Format Baru Pariwisata Yang Menyejahterakan Rakyat”, Pidato Pengukuhan Jabatan Guru Besar pada Fisipol UGM, Yogyakarta.

Dwiyanto, Agus, 2004. "Reorientasi Ilmu Administrasi Publik: Dari Government Ke Governance", Pidato Pengukuhan Jabatan Guru Besar, Yogyakarta: Fisipol UGM.

Dwiyanto, Agus, 2012. Manajemen Pelayanan Publik: Peduli, Inklusif, dan Kolaboratif, Yogyakarta: Gadjah Mada University Press.

Hall, C. Michael, 1999, "Rethinking Collaboration and Partnership: A Public Policy Perspective", Journal of Sustainable Tourism, Vol 7 No. 3 \& 4.

Munro, H.A.D., Roberts, M., \& Skelcher, C., 2008. "Partnership Governance and Democratic Effectiveness: Community Leaders and Public Managers as Dual Intermediaries", Public Policy and Administration, 23(1):61-79.

Rachayuningsih, Eny, 2010, Kebijakan Kemitraan Publik, Privat Dan Masyarakat Dalam Pengembangan Pariwisata, Studi Tentang Kebijakan Kemitraan Dalam Pengembangan Pariwisata di Malang Raya, Disertasi, FIA Universitas Brawijaya, Malang: Tidak Diterbitkan.

Zadek, Simon and Sasha Radovich, 2006, "Governing Collaborative Governance, Enhanching Develpment Outcomes by Improving Partnership Governance and Accountability.

Zaenuri, Muchamad, Sumartono, Soesilo Zauhar and Andy Fefta Wijaya, 2015, "Tourism Affair Management with Collaborative Governance Approach, Tourism Affairs Management Studies in Sleman Regency, Yogyakarta", International Journal of Management and Administrative Sciences, Vol 2, No. 06, p. 01-14. 